DOI: 10.12731/2658-4034-2020-1-25-31

\title{
ЦЕННОСТНЫЕ ОРИЕНТАЦИИ СОВРЕМЕННОГО СТУДЕНТА
}

\section{Кожевникова О.A.}

Российский государственный профессионально-педагогический университет, г. Екатеринбург, Российская Федерация

С иелью определения сформированности цеенностного отношения $\kappa$ здоровому образу жизни студентов было проведено исследование среди обучающихся 2-го курса факультета Спорта и безопасности жизнедеятельности Нижнетагильского государственного социально-педагогического института. Диагностический инструментарий данного исследования представлен двумя методиками: тест «Ценностные ориентащчи» М. Рокича в адаптаџии М.Г. Колосниковой u тест "Диагностика смысло-жизненных ориентаций подростков» П.В. Степанова и Д.В. Григорьева. Нами определено, что среди смысло-жизненных ориентащий у подростков наиболее актуальны иенности физического здоровья, иченности психического здоровья и ченности духовного здоровья.

Ключевые слова: здоровый образ жизни; иченностные ориентации; смысло-жизненные ориентации; иенностное отношение; формирование изенностей здорового образа жизни.

\section{VALUE ORIENTATIONS OF THE MODERN STUDENT}

\section{Kozhevnikova O.A.}

Russian State Vocational Pedagogical University, Yekaterinburg, Russian Federation

In order to determine the formation of a value attitude to a healthy lifestyle of students, a study was conducted among students of the 2nd year of the fac- 
ulty of Sports and life safety of the Nizhny Tagil state social and pedagogical Institute. The diagnostic tools of this study are presented by two methods: the test "Value orientations" by M. Rokich in the adaptation of M.G. Kolosnikova and the test "Diagnostics of meaning-life orientations of adolescents" by P.V. Stepanov and D.V. Grigoriev. We have determined that the values of physical health, values of mental health and values of spiritual health are the most relevant among meaningful life orientations in adolescents.

Keywords: healthy lifestyle; value orientations; meaning-life orientations; value attitude; formation of values of a healthy lifestyle.

Здоровье человека неотделимо от его жизнедеятельности и ценно тем, что является непременным условием социальной активности и трудоспособности индивидуума. Существует целый ряд определений, которые, как правило, содержат пять критериев, определяющих здоровье человека:

1. Полное физическое, духовное, умственное и социальное благополучие;

2. Нормальное функционирование организма в системе «человек - окружающая среда»;

3. Умение приспосабливаться к постоянно меняющимся условиям существования в окружающей среде;

4. Отсутствие болезни;

5. Способность к полноценному выполнению основных социальных функций [4].

Можно сделать вывод, что состояние здоровья каждого человека на 70\% индивидуально [1]. Оно зависит от наследственности [3], а в основном от индивидуального образа жизни, Т.е. от поведения, привычек, поступков, стремлений [2]. Иными словами, для сохранения и укрепления здоровья нужны собственные, постоянные и значительные усилия [5].

Цель исследовательской деятельности состояла в том, чтобы определить сформированность социально-приемлемых ценностей, особенно ценностей ЗОЖ.

Методы формирования ценностей здорового образа жизни описаны многими психологами и педагогами, однако до сих пор единства 
мнений не выявлено. Методы формирования ценностей здорового образа жизни - это группа методов, направленная на формирование и закрепление положительного отношения к сохранению и укреплению своего здоровья.

Исследование проводилось на базе НТГСПИ (ф) РГППУ.

Всего в исследовании принимали участие студенты 2-го курса факультета Спорта и безопасности жизнедеятельности Нижнетагильского государственного социально-педагогического института в составе 19 человек.

Диагностический инструментарий данного исследования представлен двумя методиками:

1. Тест позволяющий определить «Ценностные ориентации» М. Рокича в адаптации М.Г. Колосниковой.

2. Тест «Диагностика смысло-жизненных ориентаций подростков» П.В. Степанова, Д.В. Григорьева.

По методике «Ценностные ориентации» М.Рокича в адаптации М.Г. Колосниковой было выявлено, что преобладают следующие ценностные ориентации:

- 94,7\% подростков - любовь;

- 78,9\% подростков - здоровье;

- 78,9\% подростков - семья;

- $\quad$ 47,4\% подростков - дети;

- 36,8\% подростков - богатство;

- 31,6\% подростков - красота;

- $26,3 \%$ подростков - работа;

- $15,8 \%$ подростков - авторитет;

- 10,5\% подростков - мирная обстановка;

- $10,5 \%$ подростков - оптимизм;

- $10,5 \%$ подростков - ЗОЖ.

Полученные данные свидетельствуют о том, что ведущими ценностями являются социально-приемлемые ценностные ориентации. Ведущие ценности у ребят - любовь, семья и здоровье. Это те сферы жизни, значение которых ребята оценивают в собственной жизни максимально высоко. Следовательно, уроки ОБЖ, учитывающие интересы старшеклассников, направленные на формирование цен- 
ностей здорового образа жизни должны быть касаться тем семьи, здоровья и красоты. Именно поэтому в рамках данного исследования, на формирующем этапе исследования, были проведены уроки по теме «Основы медицинских знаний и здорового образа».

В то же время ведущими ценностями подростков являются:

- $100 \%$ подростков - друзья;

- $52,6 \%$ подростков - богатство;

- $52,6 \%$ подростков - красота;

- $52,6 \%$ подростков - свобода;

- $\quad$ 47,4\% подростков - здоровье;

- $\quad 42,1 \%$ подростков - любовь;

- 36,9\% подростков - ЗОЖ;

- $31,6 \%$ подростков - семья;

- 26,3\% подростков - признание;

- $21 \%$ подростков - дети;

- $15,8 \%$ подростков - авторитет;

- $15,8 \%$ подростков - мирная обстановка;

Сравнивая результаты диагностики подростков установлено, что если ведущей ценностью являются общение с друзьями (100\%), эта сфера менее актуальная чем, к примеру, сфера любви или семьи, поскольку ведущим видом деятельности контрольной группы является общение со сверстниками, а ведущим видом деятельности является профессиональное самоопределение, любовь, подготовка к браку.

Анализируя результаты диагностики по методике «Изучение смысложизненных ориентаций подростков» П.В. Степанова и Д.В. Григорьева заметно, что для подростков наиболее актуальны такие смысло-жизненные ориентации как: отношение к миру $(8,57$ средне-групповой балл), отношение к Отечеству (7,68 б.), отношение к труду (4,95 б.). Менее всего для участников экспериментальной группы такие смысло-жизненные ценности как: отношение к культуре (2,57 б.), отношение к человеку (2,47 б.), отношение к душевному Я (3,53 б.), отношение к духовному Я (3,68 б.). Наглядно эти данные представлены на рисунке № 4.

В то же время, среди подростков также наиболее актуальны такие смысло-жизненные ориентации как: отношение к отечеству (9,79 б.), 
отношение к миру (8,05 б.), отношение к знаниям (7, 11 б.), отношение к телесному Я $(5,95$ б.). Наглядно эти данные представлены на рисунке 5.

Также менее актуальны такие ценности как: отношение к духовному Я $(2,26$ б.), отношение к иному, то есть социальная толерантность (отношения к людям иной национальности, религии, состоянию здоровья и т.п.).

Необходимо подчеркнуть, что учащиеся неоднозначно относятся к своему физическому, психическому и духовному здоровью.

По методике «Изучение ценностных ориентаций» М. Рокича в адаптации М.Г. Колосниковой было выявлено, что изменились ценности подростков:

- $89,4 \%$ подростков - семья;

- $84,2 \%$ подростков - здоровье;

- 78,9\% подростков - любовь;

- $68,4 \%$ подростков - 3ОЖ;

- 47,4\% подростков - дети;

- 26,3\% подростков - богатство;

- 26,3\%подростков - красота;

- $26,3 \%$ подростков - свобода;

- $21 \%$ подростков - работа;

- $10,5 \%$ подростков - мир в стране;

- $10,5 \%$ подростков - авторитет;

- $10,5 \%$ подростков - оптимизм.

В то же время среди подростков ценностные ориентации практически не изменились. Как и прежде, для подростков контрольной группы наиболее значимы такие ценности как:

- $100 \%$ подростков - друзья;

- 52,6\% подростков - богатство;

- 52,6\% подростков - красота;

- $52,6 \%$ подростков - свобода;

- $\quad$ 47,4\% подростков - здоровье;

- $\quad$ 42,1\% подростков - любовь;

- 36,9\% подростков - ЗОЖ;

- $31,6 \%$ подростков - семья;

- 26,3\% подростков - признание; 
- $21 \%$ подростков - дети;

- $15,8 \%$ подростков - авторитет;

- $15,8 \%$ подростков - мирная обстановка.

Сравнивая результаты диагностики подростков заметно, что на контрольном этапе исследования ценности здорового образа жизни у старшеклассников гораздо более выражены.

Как и прежде, очень важны ценности семьи и брака $(89,4 \%)$, Эти же тенденции наблюдаются и в отношении детей.

По методике «Смысло-жизненные ориентации подростков» было выявлено, что резко изменилось отношение учащихся к своему физическому (с 5,32 б. до 11,05 б.), психическому (с 3,53 б. ДО 10,42 б.) и духовному (с 3,68 б. до 10,11 б.) здоровью. На контрольном этапе исследования старшеклассники испытывают устойчиво-позитивное отношение к своему здоровью. Это проявляется в том, что ребята верят в свои силы и возможности, честно относятся к себе, искренни в проявлении чувств. Они комфортно чувствует себя даже в незнакомой компании. Они не боятся одиночества, минуты уединения для них важны и плодотворны. Они стойко переносят личные неурядицы, не боятся показаться смешными.

Этого нельзя сказать о подростках. Как и на констатирующем этапе исследования, на контрольном этапе отношение подростков к своему физическому, психическому и душевному здоровью осталось на прежнем уровне.

Сравнивая смысло-жизненные ориентации учащихся заметно, что гораздо более актуальны ценности физического здоровья. Также для учащихся более актуальны ценности психического здоровья. Кроме того, для учащихся более актуальны ценности духовного здоровья.

Все вышеизложенное позволяет считать уроки ОБЖ по теме «Основы медицинских знаний и здорового образа жизни», направленные на формирование ценностей здорового образа жизни достаточно эффективными, имеющими высокий психолого-педагогический потенциал.

Таким образом, в современной литературе ценностные ориентации определяются как система личностных установок по отношению к существующим в обществе материальным и духовным ценностям. 
Это совокупность убеждений, принимаемых индивидом как свои собственные внутренние ориентиры.

В формировании ценностных представлений личности большой педагогический потенциал имеют уроки безопасности жизнедеятельности. Формирование системы ценностных представлений подростков на уроках ОБЖ основывается на шести универсальных ценностях: нравственность, здоровье, безопасность, успех, счастье, красота. Было выявлено, что гораздо более актуальны ценности физического, психического и духовного здоровья, что позволяет считать уроки ОБЖ по теме «Основы медицинских знаний и здорового образа жизни», направленные на формирование ценностей здорового образа жизни достаточно эффективными, имеющими высокий психолого-педагогический потенциал.

\section{Список литературы}

1. Барсукова С. Неформальная экономика и система ценностей россиян. СОЦИС 2018; 1: 57-60.

2. Башкирова Е. Трансформация ценностей российского общества. Полис 2018; 6: 51-56.

3. Гаврилюк В., Триказ Н. Динамика ценностных ориентации в период социальной трансформации. СОЦИС 2017; 1: 99-102.

4. Лисовский В. Духовный мир и ценностные ориентации молодежи России. СПб.: Питер 2016; 174 с.

5. Петровская Е.К. Что такое ЗОЖ. Начало разговора о важном. Физическая культура в школе 2006; 5: 54-56.

\section{References}

1. Barsukova S. Neformal'naya ekonomika i sistema tsennostey rossiyan. SOTsIS 2018; 1: 57-60.

2. Bashkirova E. Transformatsiya tsennostey rossiyskogo obshchestva. Polis 2018; 6: 51-56.

3. Gavrilyuk V., Trikaz N. Dinamika tsennostnykh orientatsii v period sotsial'noy transformatsii. SOTsIS 2017; 1: 99-102.

4. Lisovskiy V. Dukhovnyy mir i tsennostnye orientatsii molodezhi Rossii. SPb.: Piter 2016; 174 s.

5. Petrovskaya E.K. Chto takoe ZOZh. Nachalo razgovora o vazhnom. Fizicheskaya kul'tura v shkole 2006; 5: 54-56. 